\title{
Field Performance of Insecticides Treatments against the Immature and Adult Stages of Whitefly on Tomato Plant
}

\author{
Mona A.A. Mahmoud 1
}

\begin{abstract}
Field experiments were carried out during 2015 and 2016 seasons at the experimental farm, Faculty of Agriculture, Saba-Basha, Alexandria University to evaluate the efficacy Prev-AM ${ }^{\circledR}$ Planta $^{\circledR}$ and Mospilan ${ }^{\circledR}$ against $B$. tabaci on tomato plants. prev- $\mathrm{AM}^{\circledR}$ achieved the highest initial and residual reduction \% of whitefly adults giving $(84.8 \%, 69.7 \%)$, respectively. Planta ${ }^{\circledR}$ achieved the highest initial and residual reduction\% of whitefly immature giving $(\mathbf{7 8 . 7 \%}, 81.2 \%)$, respectively. On the other hand Mospilan ${ }^{\circledR}$ achieved the least initial effect. Sequence 4 (prev-AM $^{\circledR}$, Planta ${ }^{\circledR}$ ) recorded the highest initial and residual reduction $\%$ of whitefly adult giving $(86.3 \%, 83.1 \%)$, respectively. Sequence 5 (Planta ${ }^{\circledR}$, Mospilan $\left.{ }^{\circledR}\right)$ gave the highest initial and residual reduction\% of whitefly immature giving $(89.2 \%, 88.8 \%)$, respectively. Natural pesticides based on plant-essential oils may represent alternative crop protectants. From this study, orange oil and pyriproxyfen may introduce an effective control agents against whitefly in tomato field.
\end{abstract}

Key words: Bemisia tabaci, tomato plants, insecticide sequences.

\section{INTRODUCTION}

Tomato, Lycopersicon esculentum Mill is considered to be one of the most important vegetable crops for consumption and processing. It is a rich source of lycopene, beta-carotene, folate, potassium, vitamin $\mathrm{C}$, flavonoids, and vitamin $\mathrm{E}$ (Willcox et al., 2003; Bose and Agrawal, 2007). Tomato is exposed to a great number of insect pests. Insects attacking tomato plants are becoming increasingly difficult to control in the field in particular. Among the dangerous pests which attacking tomato is whitefly, Bemisia tabaci (Gennadius) (Hemiptera: Aleyrodidae)

Whitefly is attacking various vegetable, ornamental and field crops (Byrne and Bellows, 1991; Oliveira et al., 2001; Stansly and Naranjo, 2010). It directly damages the plant by feeding on phloem sap, and excretes honeydew on the leaves and fruits. This sticky and sugary surface is suitable for the growth of black sooty mold fungi that stain the crop and cover the leaves, thus preventing proper photosynthesis. In addition, stickiness and discoloration greatly reduce the value of agricultural crops such as ornamental, vegetables and cotton. Also, B. tabaci is a vector of several important families of plant viruses (Jones, 2003;
Hogenhout et al., 2008). In some crops (e.g. tomatoes and cassava) the resulting virus diseases are limiting growth factors and may cause total crop loss. Mostly, this insect pest is controlled by synthetic insecticides. Such reliance is expected to increase tolerance or the development of resistance in addition to the adverse effects on non-target organisms (Palumbo et al., 2001). To overcome these problems, insect control alternatives must be used for management of this insect such as pyriproxyfen and orange oil.

Pyriproxyfen is a potent juvenile hormone (JH) mimic, affecting the hormonal balance in insects, suppressing embryogenesis, metamorphosis and adult formation (Itaya, 1987; Langley, 1990; Koehler and Patterson, 1991). It has been considered a leading insecticide for controlling whiteflies (Ishaaya and Horowitz, 1995; Crowder et al., 2008; Castle et al., 2010), especially biotype B. Therefore, the aim of the present work was to evaluate orange oil, pyriproxyfen and acetamiprid against B. tabaci in tomato field. Also, some sequences of these insecticides were evaluated for successive control of this insect.

\section{MATERIALS AND METHODS}

\section{Tested insecticides:}

Acetamiprid (Mospilan $^{\circledR}$ 20\%SP) supplied by Nippon Soda Co., Ltd. was used at field rate of $25 \mathrm{~g} / 100$ liter water. Orange oil (Prev- AM ${ }^{\circledR} 6 \% \mathrm{SL}$ ) provided by Bridgetrade comp., was used at field rate of $400 \mathrm{ml} / 100$ liter water. Pyriproxyfen (Planta ${ }^{\circledR} 10 \%$ EC) was used at field rate of $75 \mathrm{ml} / 100$ liter water.

Field experiments were carried out during two successive summer seasons of 2015 and 2016 at the experimental farm, Faculty of Agriculture, Saba-Basha, Alexandria. One variety of tomato (6112) was used during the course of this study and cultivated on May 11 and May 15, at 2015 and 2016 season. Treatments were arranged in a randomized complete block design (RCBD). Each treatment was replicated three times (42 $\mathrm{m}^{2}$ each). The normal agricultural practices were applied. The insecticides were sprayed by Knapsack sprayer equipment (CP3) at the rate of 200 liter per feddan. Control was sprayed only by water.

The inspection samples of whitefly adult individuals were carried out before treatment and 1day, 5, 7 and 10

${ }^{1}$ Plant Protection Research Institute, ARC, Bacous, Sabahia, Alexandria Egypt.

Received August 27, 2017, Accepted September 28, 2017 
days post treatment (residual effect). Counts were done in the early morning for adults when flight activity is minimal according to Bulter et al., (1988). Ten leaves were picked at random from each plot and put in numbered paper bags and transferred to the laboratory for examining the immature stages by using stereoscopic binocular microscope.

The reduction percentages in numbers of whitefly adults and immature stages were calculated in accordance to Henderson and Tilton's equation (1955). Treatments were compared with each other using one way ANOVA with $\operatorname{LSD}_{0.05}$ (CoStat Statistical Software, 1990).

\section{RERSULTS}

Reduction percentages of whitefly adults and immature as a result of some insecticide treatments: (2015)

According to the general means of initial and residual effects in season 2015, whitefly populations were significantly reduced by the insecticide treatments (Table 1). Results indicated that, Prev-AM ${ }^{\circledR}$ and Planta ${ }^{\circledR}$ achieved the highest initial (24hr) reduction $\%$ of whitefly adults with general mean $84.8 \%$ and $77.8 \%$, respectively. On the other hand, Mospilan ${ }^{\circledR}$ achieved the least initial reduction with general mean 57.3\%. Prev$\mathrm{AM}^{\circledR}$ gave the highest residual toxicity against whitefly adults followed by Mospilan ${ }^{\circledR}$ which is followed by Planta ${ }^{\circledR}$ with general means reduction $69.7 \%, 57.3 \%$ and $54.6 \%$, respectively.

Regarding the whitefly immature stage (Table 2), Planta ${ }^{B}$ gave the highest initial reduction $\%$ with general mean $78.7 \%$ followed by Prev- $\mathrm{AM}^{\circledR} 63.0 \%$ which is followed by Mospilan $60.4 \%$. The general mean reduction percentages of immature stage for the residual effect revealed that, Planta was the most effective treatment giving $81.2 \%$ followed by Prev-AM ${ }^{\circledR}$ with $66.5 \%$ which is followed by Mospilan with $38.7 \%$.

Reduction percentages of whitefly adults and immature as a result of some sequence of insecticide treatments (2016):

At season 2016, the exhibited data in Table (3) demonstrate the calculated reduction percentages of whiteflies after application of the six suggested sequences of tested insecticides. All tested insecticide sequences significantly reduced the numbers of whitefly adult stage. Sequence 4 (Prev-AM ${ }^{\circledR}$, Planta ${ }^{\circledR}$ ) recorded the highest initial reduction $\%$ of whitefly adult with general mean $86.3 \%$, followed by sequence 3 (Prev$\mathrm{AM}^{\circledR}$, Mospilan ${ }^{\circledR}$ ) with $81.2 \%$ reduction. On the other hand, sequence 1 (Mospilan $^{\$}$, Planta ${ }^{\circledR}$ ) achieved the least initial effect with $64.0 \%$ reduction. According to the general mean reduction percentages of residual effect against the adult stage, sequence 4 achieved the highest efficiency, with $83.1 \%$ reduction followed by sequence 3 (Prev-AM ${ }^{\circledR}$, Mospilan ${ }^{\circledR}$ ) giving 78.1\% reduction. On the other hand, sequence 1 exhibited the lowest residual efficacy.

Results in Table (4) show the initial and residual general mean reduction percentages of whitefly immature stage as a result of some insecticide sequences treatments. Sequence 5 (Planta $^{\text {, }}$, Mospilan ${ }^{\text {}}$ ) gave the highest initial reduction $\%$ with general mean $89.3 \%$. There were no significant differences among other sequences. Regarding the general mean reduction percentages of residual effect, sequence 5 recorded the highest reduction $88.9 \%$ followed by sequence $6(85.1 \%$ reduction). However, sequence 2 achieved the least residual effect $(70.1 \%)$.

\section{DISCUSSION}

The sweet potato whitefly $B$. tabaci is an important pest of many plant crops, vegetables and ornamentals (Oliveira et al., 2001). Damage by B. tabaci is caused by its sap-sucking activity, vectoring plant diseases and secreting honeydew that promotes the growth of sooty mould (Obeng-Ofori, 2007). Bemisia pest management programs are usually based on insecticide applications, but these products are often toxic to the environment and to non-target species. Therefore, it is important to search about more safe and effective alternatives to control this insect pest. In the present study, the IGR compound, pyriproxyfen and the orange oil are compared with acetamiprid for the whitefly control in tomato field. Some insecticide sequences were also evaluated.

Results indicated that, orange oil (Prev-AM ${ }^{\circledR}$ ) and pyriproxyfen (Planta ${ }^{\circledR}$ ) achieved a good control of both adult and immature stages of whitefly. In addition, Sequence 5 (Planta $^{\text {, Mospilan }}{ }^{\text {}}$ ) gave the highest control of whitefly adult and immature stages. These results are in agreement with those of Isaac and Horowitz (2006) who mentioned that treatment of whitefly larvae with $0.04-5 \mathrm{mg} \mathrm{L}^{-1}$ of pyriproxyfen resulted in normal development until the pupal stage; however, adult emergence was totally suppressed. Second instar of B. tabaci exposed to $5 \mathrm{mg} \mathrm{L}^{-1}$ pyriproxyfen, excreted honeydew at a level similar to the control level until the $4^{\text {th }}$ instar (pupation), after which a strong reduction was observed. Inhibition of egg-hatch on the lower surface of cotton leaves was observed when their upper surface was treated with 1$25 \mathrm{mg} \mathrm{\textrm {L } ^ { - 1 }}$ pyriproxyfen, indicating a pronounced translaminar effect. 


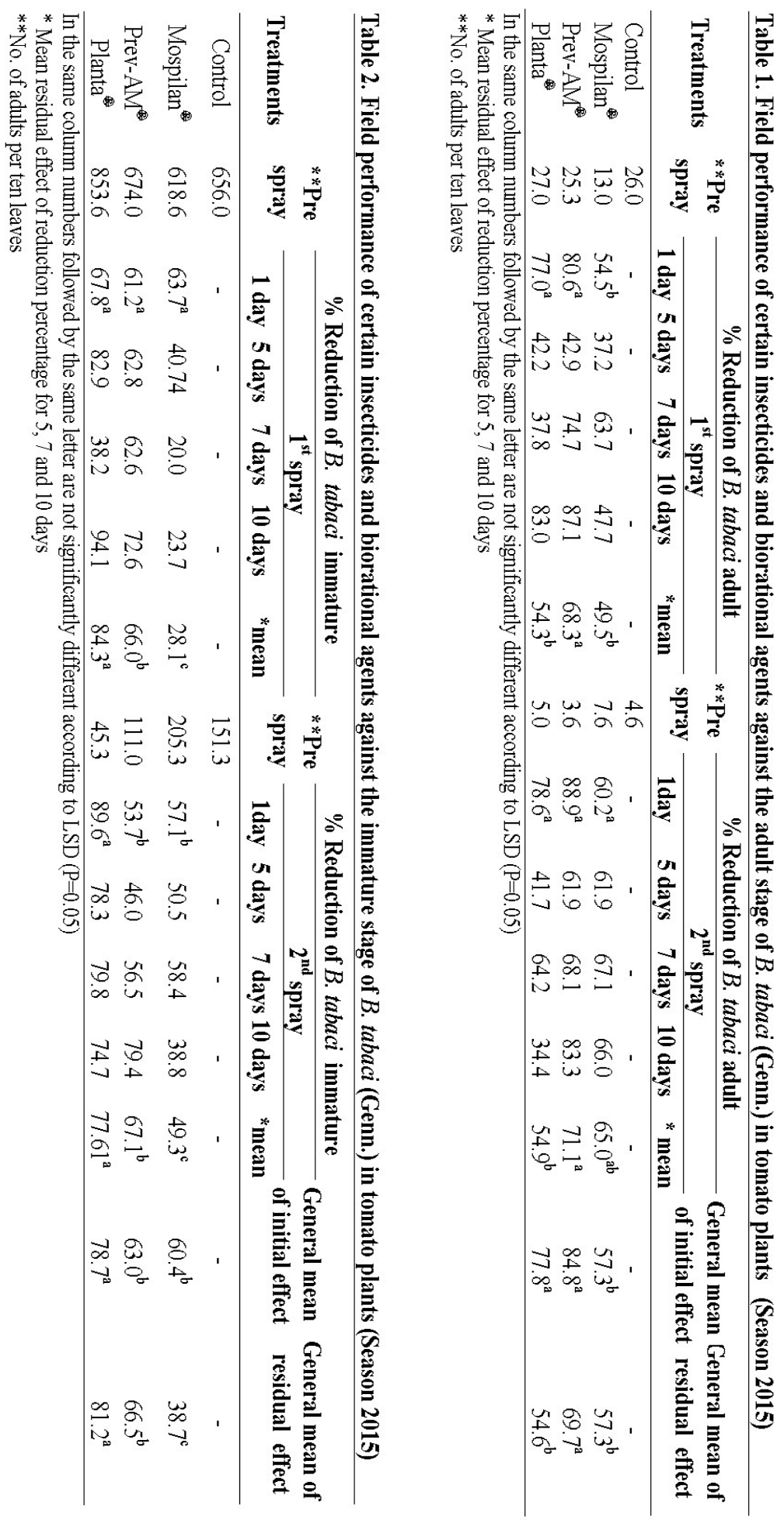




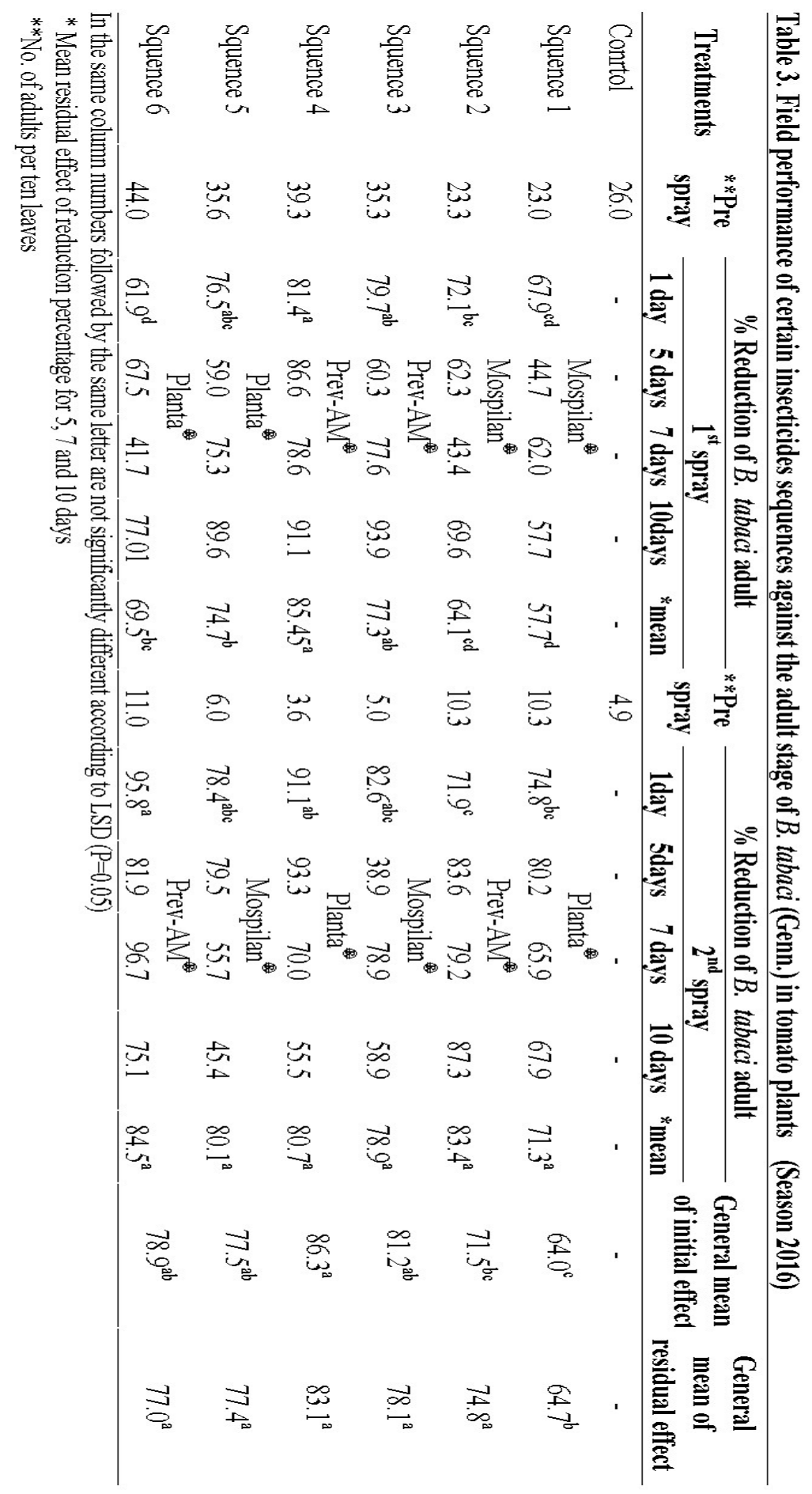




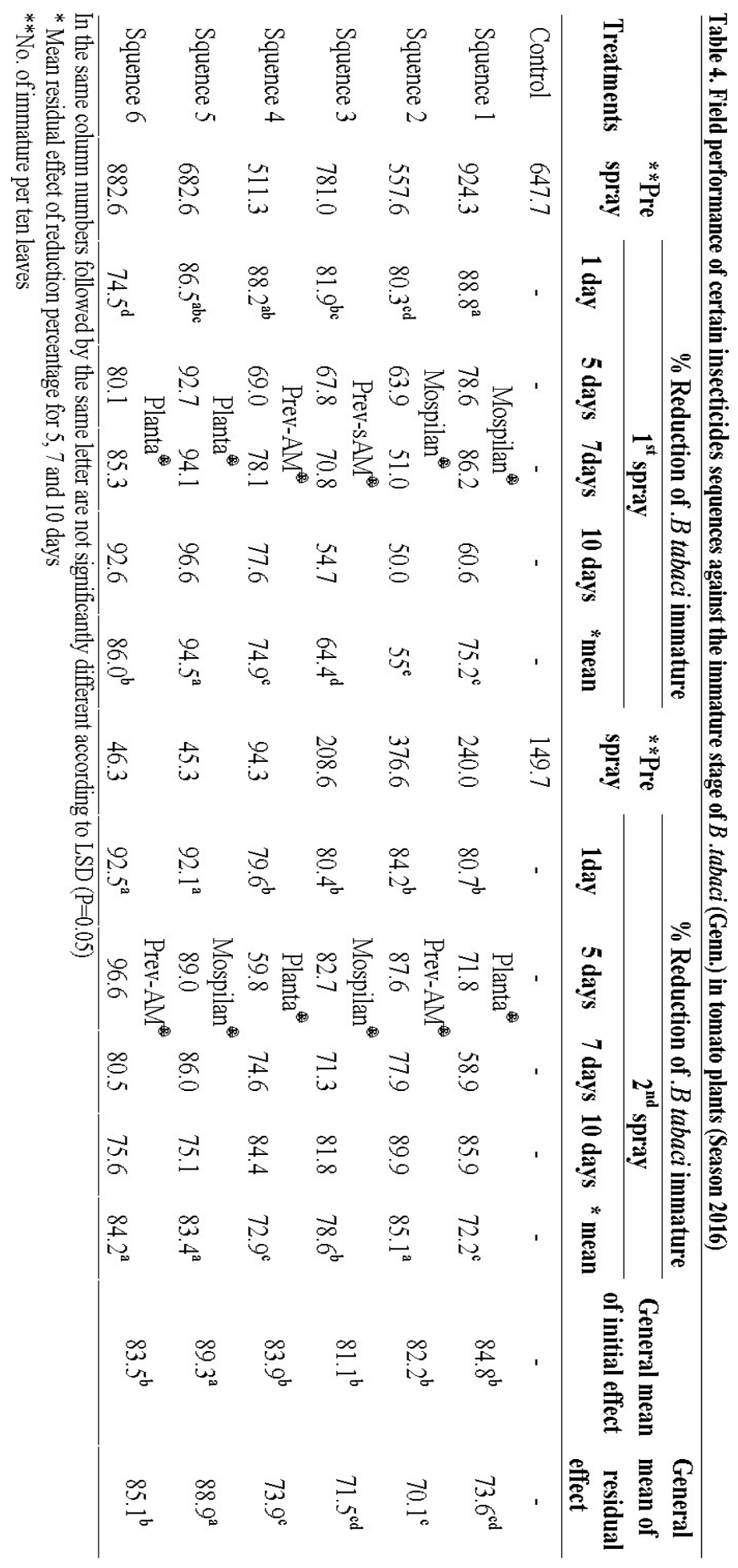


These findings indicate that pyriproxyfen is an efficient control agent of B. tabaci. In addition, Naranjo (2001) reported that if growers rely on softer chemicals, such as IGRs, they may increase the population of natural enemies (predators, parasitoids and pathogens). When pyriproxyfen and buprofezin were used for whitefly control on cotton, they are much more selective than the broad-spectrum conventional insecticides and do not affect several predator taxa (Naranjo et al., 2002; Naranjo and Akey, 2004).

On the other hand, El-Aswad and Abou-Taleb (2008) evaluated different regimens of some insecticides in controlling cotton bollworm, they found that the sequence No.5 (spinosad, chlorpyrifos, spinosad and carbosulfan) achieved high efficacy against Pectinophora gossypiella which gave the reduction percentage of 87.6 and 88.1 while, the sequence No.4 (deltamethrin, chlorpyrifos, deltamethrin and carbosulfan) achieved superior efficacy against Earias insulana which gave 89.3 and 92.5 reduction of infestation throughout season 2006 and 2007, respectively.

The use of plant extracts, including allelochemical compounds such as essential oils, with known effects on insects, could be a useful complementary or alternative method to the heavy use of classical insecticides. This could improve the biodegradability of insecticide treatments and therefore decrease the quantity of toxic insecticide residues, increase insecticide selectivity and develop a better respect for the environment. Various essential oils are documented to exhibit acute toxic effects against insects (García et al., 2007; Rajendran and Sriranjini, 2008; López and Pascual-Villalobos, 2010). Eucalyptus and citrus oils, such as lemon and orange, are widely utilized in various industries and are of low cost. Our results are compatible with results of Shehata et al., (2009), where they reported that prev recorded good reduction in whitefly numbers on cucumber plant.

Finally, concerns over health and environmental problems associated with synthetic insecticides currently in use in agriculture have led to an intensification of efforts to find safe alternatives. Plants may provide potential alternatives to currently used insect-control agents because they constitute a rich source of bioactive chemicals. Natural pesticides based on plant-essential oils may represent alternative crop protectants. From this study, orange oil and pyriproxyfen may introduce and effective control agents against whitefly in tomato field.

\section{REFERENCES}

Bose, K.S. and B.K. Agrawal. 2007. Effect of lycopene from cooked tomatoes on serum antioxidant enzymes, lipid peroxidation rate and lipid profile in coronary heart disease. Singapore Med J. 48: 415-420.

Butler, G.D., D.L. Coudriet and T.V. Hennebery. 1988. Toxicity and repellance of soybeans and cottonseed oils to the sweet potato whitefly and the aphids on cotton in greenhouse studies. Southwest, Entomol. 13: 81-96.

Byrne, D.N. and T.S. Jr. Bellows. 1991. Whitefly biology. Annu Rev Entomol. 36:431-457.

Castle, S.J., J.C. Plumbo, N. Prabhaker, A.R. Horowitz and I.Denholm. 2010. Ecological determinants of Bemisia tabaci resistance to insecticides. In: Stansly, P.A., S.E. Naranjo(eds) Bemisia tabaci: bionomics and management of global pest. Springer, Dordrecht.

CoStat Statistical Software. 1990. Microcomputer program analysis version 4.20, CoHort Software, Berkeley, CA.

Crowder, D.W., P.C.Ellsworth, B.E.Tabashnik and Y. Carriére. 2008. Effects of operational and environmental factors on evolution to pyriproxyfen in the sweet potato whitefly (Hemiptera: Aleryrodidae). Environ Entomol. 37:1514-1524.

El-Aswad, A. F. and H. K. Abou-Taleb. 2008. Influence of Certain Insecticide regimens Against Bollworms in Cotton Fields in Egypt. Alex. Sci.Exch.J. (29)1:36-44.

García, M., A.Gonzalez-Coloma, O.J. Donadel, C.E. Ardanaz, C.E. Tonn and M.E. Sosa. 2007. Insecticidal effects of Flourensia oolepis Blake (Asteraceae) essential oil. Biochem Syst Ecol 35: 181 - 187.

Henderson, C. and E. Tilton. 1955. Tests with acaricides against the brown wheat mite. J. Econ. Entomol. 48:157161.

Hogenhout, S.A, E.D. Ammar, A.E. Whitfield and M.G. Redinbaugh. 2008. Insect vector interactions with persistently transmitted viruses. Annu. Rev. Phytopathol. 46:327-359.

Itaya, W. 1987. Insect juvenile hormone analogue as an insect growth regulator. Sumitomo Pyrethroid World. 8:2-4.

Ishaaya, I. and A.R. Horowitz. 1995. Pyriproxyfen, a novel insect growth regulator for controlling whiteflies: mechanisms and resistance management. Pestic Sci. 43: 227-232.

Isaac, I. and A.R. Horowitz. 2006. Pyriproxyfen, a novel insect growth regulator for controlling whiteflies: mechanisms and resistance management. Pestic. Sci. 43: 227-232.

Jones, D.R. 2003. Plant viruses transmitted by whiteflies. Eur. J. Plant Pathol. 109:195-219.

Koehler, P.G. and R.J. Patterson. 1991. Incorporation of pyriproxyfen in German cockroach (Dictyoptera: Blattellidae) management program. J. Econ. Ent. 84:917921. 
Langley, P. 1990. Control of the tsetse fly using a juvenile hormone mimic, Pyriproxyfen. Sumitomo Pyrethroid World. 15:2-5.

López M.D. and M.J. Pascual-Villalobos. 2010. Mode of inhibition of acetylcholinesterase by monoterpenoids and implications for pest control. Ind Crop Prod 31: 284 288.

Naranjo, S.E. 2001. Conservation and evaluation of natural enemies in IPM systems for Bemisia tabaci. In: Special Issue: Challenges and Opportunities for Pest Management of Bemisia tabaci in the New Century. (eds S.E. Naranjo and P.C. Ellsworth). Crop Protection. (20)9: 835-852.

Naranjo, S.E. and D.H. Akey. 2004. Comparative efficacy and selectivity of acetamiprid for the management of Bemisia tabaci. In: 2004 Cotton Report. University of Arizona, College of Agriculture and Life Sciences, Tucson, Arizona, USA. 198-205

Naranjo, S.E., P.C. Ellsworth, C.C. Chu and T.J. Henneberry. 2002. Conservation of predatory arthropods in cotton: role of action thresholds for Bemisia tabaci (Homoptera: Aleyrodidae). J. Econ. Ent. 95: 682-691.
Obeng-Ofori, D. 2007. Major arthropod pests of root, tuber crops and plantains. In Major Pests of Food and Selected Fruit and Industrial Crops in West Africa, edited by Obeng-Ofori, D. Accra (Ghana): City Publishers. pp. 5975.

Oliveira, M.R.V., T.J. Henneberry and P. Anderson. 2001. History, current status, and collaborative research projects for Bemisia tabaci. Crop Prot. 20(9): 709-723.

Palumbo, J.C., A.R. Horowitz and N. Prabhaker. 2001. Insecticidal control and resistance management for Bemisia tabaci. Crop Protection, 20: 739-765.

Rajendran, S. and V. Sriranjini. 2008. Plant products as fumigants for stored- product insect control. J Stored Prod Res: 44: 126 - 135.

Shehata, S.A., M.A. Abd El-Latief and H.K. Abou-Taleb. 2009. Evaluation of some natural insecticides against some insects infesting cucumber and their predatory insect (Syrphus corollae F.) in the field. Alex. J. Agric. Res. 54: 49-55.

Stansly, P.A. and S.E. Naranjo. 2010. Bemisia: bionomics and management of global pest. Springer, Dordrecht.

Willcox, J.K., G.L., Catignani and S. Lazarus. 2003 Tomatoes and cardiovascular health. Crit Rev Food Sci Nutr. 43: 118.

\section{الملخص العربي}

\section{التقييم الحقلى لبعض المبيدات ضد الأبابة الإبضاء فى نبات الطماطم منى عبد الكريم عبد الظاهر محمود}

تم در اسة بعض تعاقبات المبيــدات ضـــــ أطـــــار الذبابـــه البيضناء خلال موسم 7 . ب ، وقد وجد أن التتابع الرابــع

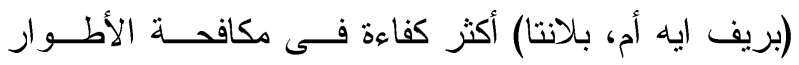

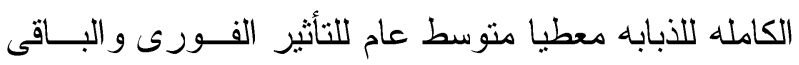

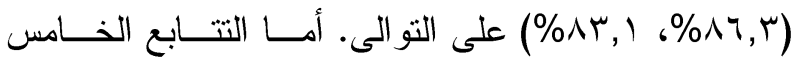
(بلانتا، موسبيلان) سجل أعلى كفاءة فى مكافحة الحوريات

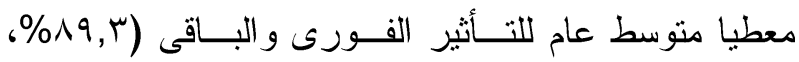
\% \% ع, 9 المبيدات الطبيعيه المحتويه على الزيوت الطياره في وقايــة المحاصبل كبدائل عن المبيدات، ونستتتج من هذه الدراســه أن زيت البرتقال، البيربوكسفين تعتبر وسائل مكافحة جيدة ضد حشرات الذباب الأبيض فى الطماطم.

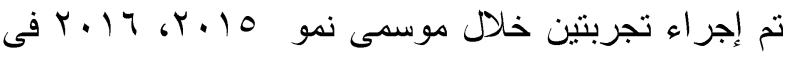

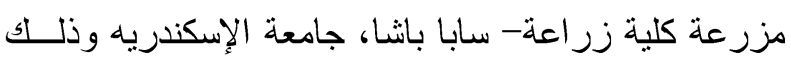
بهدف تقييم كفاءة بريف ايه أم، بلانتــا، موســبيلان فـى مكافحة الذبابة البيضناء التى تصيب نباتات الطماطم تحـــت

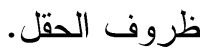
أظهرت النتائج خلال موسم 10 . أن بريف ايه أم، كان

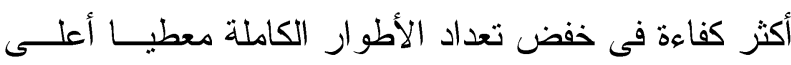

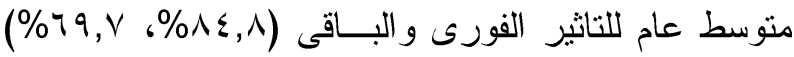
على التو الىى، مركب بلانتا سجل أعلى كفاءه فــى مكافحـــة الحوريات معطيا متوسط عام للتــأثثر الفـورى و البــاقى

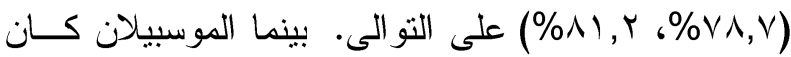
أقل المعاملات كفاءة فى مكافحة الذبابة البيضاء. 